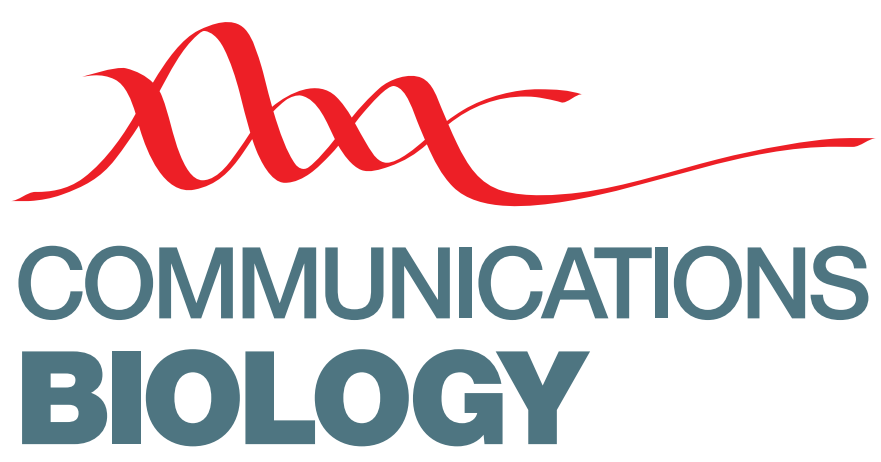

\title{
Author Correction: Ultra-high throughput single-cell analysis of proteins and RNAs by split-pool synthesis
}

Maeve O'Huallachain (D), Felice-Alessio Bava, Mary Shen, Carolina Dallett, Sri Paladugu, Nikolay Samusik, Simon Yu, Razika Hussein, Grantland R. Hillman, Samuel Higgins, Melanie Lou, Angelica Trejo, Laura Qin, Yu Chuan Tai, Shigemi M. Kinoshita, Astraea Jager, Deval Lashkari, Yury Goltsev, Sedide Ozturk \& Garry P. Nolan

Correction to: Communications Biology https://doi.org/10.1038/s42003-020-0896-2, published online 7 May 2020.

In the original published version of the article, the name of co-author Samuel Higgins was spelled incorrectly. In addition, there were minor errors in Figures 2, 3, 4, 7, and 8 that affected the clarity of the presented information. The errors have been corrected in the HTML and PDF versions of the paper.

Published online: 29 May 2020

\footnotetext{
(c) (i) Open Access This article is licensed under a Creative Commons Attribution 4.0 International License, which permits use, sharing, adaptation, distribution and reproduction in any medium or format, as long as you give appropriate credit to the original author(s) and the source, provide a link to the Creative Commons license, and indicate if changes were made. The images or other third party material in this article are included in the article's Creative Commons license, unless indicated otherwise in a credit line to the material. If material is not included in the article's Creative Commons license and your intended use is not permitted by statutory regulation or exceeds the permitted use, you will need to obtain permission directly from the copyright holder. To view a copy of this license, visit http://creativecommons.org/licenses/by/4.0/.
}

(c) The Author(s) 2020 